\title{
PENGEMBANGAN KETERAMPILAN SEKOLAH PEMUDA/I PUTUS SEKOLAH MENCIPTAKAN LAPANGAN KERJA BERWIRAUSAHA BARU DI "BUNGA MAS BERKAH" RAWANG TUNGGUL HITAM
}

\author{
Jupriani $^{1^{*}}$, Budiwirman ${ }^{2 *}$, M. Nasrul Kamal ${ }^{3 *}$ \\ Program Studi Desain Komunikasi Visual, Jurusan Seni Rupa \\ Fakultas Bahasa dan Seni \\ Universitas Negeri Padang \\ Jl. Prof. Dr. Hamta, Air Tawar Padang, Kel. Air Tawar Barat, Kec. Padang Utara, Kota Padang, Kode Pos 25171 \\ Sumatera Barat. Indonesia \\ Email: jupriani@gmail.com
}

\begin{abstract}
Abstrak
Upaya meningkatkan ekonomi masyarakat, pemberdayaan industri kecil, industri kerajinan, dan industri rumah tangga, maka perlu dilakukan berbagai kegiatan pendidikan non formal, sehingga dengan keterampilan yang dimiliki, masyarakat bisa berusaha secara mandiri. Dikarenakan jumlah pengangguran relatif banyak, maka pelaksanaan pendidikan non formal ini diprioritaskan kepada pemuda pengangguran (usia 19 - 30 tahun), yang terdapat di Kelurahan Rawang Tunggul Hitam, Koto Tangah Padang. Salah satu tujuan yang ingin dicapai adalah keterampilan merangkai berbagai bahan limbah yang dapat dijadikan sebuah karya seni rupa yang unik dan bermanfaat, serta mencetak berbagai souvenir atau yang lebih popular dengan nama cetak pin dan kartu ucapan. Dipilihnya jenis ketarampilan ini karena relatif mudah dipelajari, bahan mentah tersedia, tingkat keberhasilan usaha lebih besar. Diakhir kegiatan diperoleh kesimpulan khalayak sasaran telah memahami dan terampil dibidang merangkai bunga serta berbagai keterampilan membuat souvenir produk berupa pin dan gantungan kunci yang dapat dipasarkan. Berdasarkan temuan yang diperoleh, dapat disarankan bahwa kegiatan ini supaya dikembangkan kepada pemuda/pemudi generasi penerus sehingga tidak terdapat lagi pengangguran di Kelurahan Rawang Tunggul Hitam.
\end{abstract}

Kata Kunci: wirausaha, bunga mas berkah, rawang.

\begin{abstract}
Efforts to improve the community's economy, empowerment of small industries, handicraft industries, and home industries, it is necessary to do a variety of non-formal educational activities, so that with the skills possessed, the community can try independently. Due to the relatively large number of unemployed, the implementation of non-formal education is prioritized for unemployed youth (aged 19-30 years), which is located in Rawang Tunggul Hitam Village, Koto Tangah Padang. One of the goals to be achieved is the skill to compile various waste materials that can be used as a unique and useful work of art, as well as to print various souvenirs or more popularly by the name of printed pins and greeting cards. This type of skill was chosen because it is relatively easy to learn, raw materials are available, the level of business success is greater. At the end of the activity it was concluded that the target audience had understood and skilled in the field of flower arranging and various skills in making product souvenirs in the form of pins and key chains that could be marketed. Based on the findings obtained, it can be suggested that this activity should be developed for young people / young generation so that there will be no more unemployment in Rawang Tunggul Hitam..
\end{abstract}

Keywords: entrepreneurship, bunga mas berkah, rawang.

\section{PENDAHULUAN}

Pemuda putus sekolah memiliki potensi besar untuk menganggur, sehingga mengakibatkan jumlahnya semakin hari semakin terus meningkat. Berbagai faktor menyebabkan pengangguran, antara lain karena terlalu banyak berharap untuk menjadi pegawai negeri, belum berkembangnya jiwa wirausaha (Dirbinlitabmas, 1998), kurang mempunyai kemandirian untuk berwirausaha (Koswara, 1998; Nurtain, 1998), tidak mempunyai keterampilan sehingga belum dapat menjawab tantangan dunia kerja, dan ketiadaan biaya untuk melanjutkan pendidikan.

Situasi dan kondisi tersebut harus segera diatasi. Solusinya adalah dengan memberdayakan ekonomi masyarakat dengan pendekatan yang bertujuan menggiatkan, membina dan mengembangkan potensi setempat (bottom up). Salah satu upaya yang dapat 
dilakukan adalah dengan memberikan bekal pengetahuan dan keterampilan sehingga mereka dapat bekerja secara mandiri atau bekerja sebagai karyawan pada industri kecil menegah (IKM), sebab kekuatan perekonomian rakyat memang terletak pada IKM. Sebanyak 70\% jumlah tenaga kerja yang bekerja di sektor industri ditampung pada sub sektor IKM, Harian Kompas (5 Maret 1991).

Tingginya tingkat penyerapan tenaga kerja pada IKM disebabkan karena tidak menuntut kualifikasi tenaga kerja dengan keterampilan tinggi. IKM berakar dari keluarga, dan dikembangkan secara turun-temurun melalui pendidikan non formal. Kenyataan ini sesuai dengan pernyataan yang ditulis Dirbinlitabmas (1998), pengusaha Indonesia tumbuh dan berkembang dengan jiwa kewirausahaan secara turun temurun, bukan melalui pendidikan formal. Sedikit sekali pengusaha Indonesia yang dihasilkan dari lembaga-lembaga pendidikan tinggi.

\section{KAJIAN TEORI}

Di Sumatera Barat, IKM merupakan industri andalan jangka pendek dan menengah, hal tersebut disebabkan karena 94,8\% industri di Sumatera Barat merupakan IKM yang menyerap tenaga kerja sebanyak 105.999 orang (Kanwil Deperindag Sumatera Barat, 1995). Konstribusi sub sektor IKM terhadap produk domestik regional bruto Sumatera Barat selama lima tahun terakhir sebesar 15,79\% (Amar, 2003). Bagi Sumatera Barat, industri kerajinan yang merupakan industri rakyat jauh lebih penting dibandingkan dengan industri besar yang padat modal. Dalam Pelita V, industri kecil dan industri kerajinan rakyat mendapat prioritas untuk dikembangkan (Djabar, 1995). Gubernur Sumatera Barat menyatakan, bahwa kebijaksanaan umum pembangunan sektor industri dalam menghadapi abad 21 antara lain adalah pengembangan industri kerajinan rakyat.

Upaya meningkatkan ekonomi masyarakat, justru pemberdayaan industri kecil, industri kerajinan, dan industri rumah tangga, maka perlu dilakukan berbagai kegiatan pendidikan non formal, sehingga dengan keterampilan yang dimiliki, masyarakat bisa berusaha secara mandiri, atau berkeja pada IKM. Berhubung jumlah pengangguran relatif banyak, maka pelaksanaan pendidikan non formal ini diprioritaskan kepada pemuda menganggur yang putus sekolah, masih produktif (usia 19 - 30 tahun), miskin sehingga yang tidak sanggup untuk melanjutkan ke tingkat pendidikan yang lebih tinggi yang terdapat di Kelurahan Rawang Tunggul Hitam, Koto Tangah Padang. Berbagai jenis keterampilan dapat diberikan sebagai modal untuk berwirausaha. Salah satunya adalah keterampilan cetak mencetak Budiwirman, (2016) berbagai souvenir atau yang lebih popular dengan nama cetak pin dan kartu. Dipilihnya jenis ketarampilan ini karena relatif mudah dipelajari, bahan mentah tersedia, tingkat keberhasilan usaha lebih besar.

Pangsa pasar juga mempunyai prospek yang bagus. Produk-produk hasil cetak ini seperti PIN merayakan sesuatu kegiatan/pertunjukan, kartu-kartu ucapan seperti; kartu nama, kartu undangan, merupakan kebutuhan masyarakat kota. dengan desain dan warna yang menarik merupakan kesukaan anak muda, (Sulasmi Darma. 1989).

Keterlibatan UNP Padang dalam membina masyarakat melalui pendidikan non formal sudah sesuai dengan misi yang diembannya, yaitu mengembangkan dan menyebarluaskan ilmu pengetahuan, teknologi, kesenian, budaya serta mengupayakan penggunaannya untuk meningkatkan taraf kehidupan masyarakat. UNP memiliki sarana dan prasarana pembelajaran yang relatif lengkap, tenaga pengajar yang sudah biasa mengelola kegiatan pembelajaran kepada orang dewasa serta sudah berpengalaman melaksanakan kegiatan pembelajaran non formal pada kegiatan pengabdian kepada masyarakat, dan fasilitas kantor sebagai pusat administrasi tersedia. Untuk kegiatan on the job training (OJT), Jurusan Seni Rupa FBS memiliki Workshop/Labor Cetak mencetak beserta perangkat peralatannya. Fasilitas ini dapat dipergunakan peserta didik (warga belajar) secara maksimal untuk kegiatan belajar keterampilan cetak.

Permasalahan mitra ini berdasarkan rencana kegiatan yang telah disusun maka target luaran yang diharapkan setelah pelaksanaan Program Kemitraan Masyarakat (PKM). Disamping itu, hasil dari kegiatan ini juga akan digunakan untuk menyusun luaran berupa Jurnal Nasional ber ISSN hasil dari pengabdian masyarakat yang telah dilakukan serta publikasi ilmiah.

\section{METODE PENELITIAN}

Metode Pendekatan Yang Ditawarkan Masalah perlu dicarikan jalan keluarnya dengan Mitra dan mencapai target luaran yang sudah direncanakan, maka metode pelaksanaan yang ditawarkan adalah metode workshop. Metode ini dianggap paling efektif karena mencakup pemberian teori dan praktek. Berikut dijabarkan tahapan-tahapan pelaksanaan kegiatan sehingga tujuan dari kegiatan ini dapat tercapai:

* Diawali dengan memaparkan dan memberi teoriteori tentang desain cetak-mencetak dan keilmuan membuat desain berbagai souvenir. 


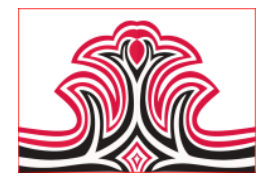

* Memberikan pengetahuan dan pemahaman dasardasar tentang manfaat

* Mempelajari teknik cetak-mencetak, elemen desain dan prinsipnya.

Aspek ekonomi desain cetak-mencetak umumnya digunakan untuk kepentingan promosi atau komunikasi pemasaran agar produk-produk rancangan dapat dikenal baik oleh masyarakat atau untuk perluasan pangsa pasar. Hal ini tentu sangat diperlukan bagi setiap produk cetak untuk dikenal dan mempunyai nilai jual yang baik ditengah kompetisi pasar yang semakin kompetitif.

\section{HASIL DAN PEMBAHASAN}

\section{Hasil}

Sebagian besar kegiatan telah dilaksanakan, berikut ini akan dijelaskan jenis kegiatan dan hasil yang dicapai sesuai dengan langkah-langkah kegiatan: Persiapan Administrasi dan rekrutmen peserta pengabdian ini dilaksanakan untuk pemuda-pemudi Putus Sekolah di “Bunga Mas Berkah" Rawang Tunggul Hitam Padang. Beberapa kegiatan yang sudah dilaksanakan adalah: Penyusunan perencanaan teknis pengabdian ini meliputi perbaikan proposal yang sudah disetujui, kegiatan ini dilakukan oleh tim pengabdian untuk memperbaiki saran-saran yang dikemukakan oleh reviewer pengabdian. Selanjutnya tim pengabdian mendiskusikan penyusunan perencanaan teknik pengabdian, Hasil yang diperoleh dari kegiatan ini meliputi :

* Melakukan pemantapan lokasi pengabdian

* Perencanaan pengurusan izin pengabdian

* Perencanaan perekrutan peserta

* Pemantapan jadwal dan rencana operasional

* Penulisan materi Pelaksanaan pelatihan

* Pemantauan dan pembimbingan

* Evaluasi kegiatan

* Penulisan laporan kegiatan

Pelaksanaan dari perencanaan yang dari 8 ( Delapan) kegiatan yang telah dijadwalkan dan direncanakan yang telah terlaksana adalah:

*Melaksanakan pemantapan lokasi

Pemantapan lokasi pelatihan yang akan diadakannya pengabdian dilaksanakan dengan melakukan survey ke lokasi pengabdian dan menghubungi camat dan lurah menjelaskan tentang perencanaan yang akan dilaksanakan di daerahnya. Secara terbuka mereka menyatakan kesediaan peserta dengan memfasilitasi akan tempat pelaksanaan pengabdian (pelatihan)

*Melakukan pengurusan izin pengabdian ke Pemda Kota Padang setelah dari sana, kecamatan sampai
Gorga : Jurnal Seni Rupa

Volume 08 Nomor 02 Juli-Desember 2019 p-ISSN: 2301-5942 | e-ISSN: 2580-2380

ke kelurahan yang menjadi lokasi pengabdian yaitu kelurahan Rawang Tunggul Hitam Kota padang.

*Perencanaan perekrutan peserta yang akan mengikuti telah dilakukan dengan menemui bapak Lurah setempat untuk menunjuk peserta sebanyak jumlah yang ditentukan ketua pengabdian dan sudah disepakati sebanyak 15 orang peserta yang mewakili kelurahan

*Pemantapan jadwal dan rencana operasional pengabdian yang telah dilakukan dengan menghubungi Bapak Lurah yang bersangkutan

*Penulisan materi yang akan disampaikan pada pelatihan yang ditugaskan kepada instruktur untuk menulis materi

*Pelaksanaan pelatihan tersebut, dengan digabungkannya beberapa bidang keahlian, maka terwujud satu kesatuan ilmu untuk peserta pelatihan. Diawali dengan membuat desain sampai kepada wujud atau produk yang dirancang sesuai dengan materi yang ditawarkan. Maka terwujud beberapa hasil karya merangkai bunga berupa pin, dan bros serta gelang. Melalui kegiatan ini peserta memiliki keterampilan membuat karya fungsional untuk interior dan hiasan dengan teknik merangkai, merakit. Dengan begitu perguruan tinggi seni khususnya UNP Padang yang telah melakukan kegiatan pengabdian terhadap masyarakat Rawang Tunggul Hitam Kota padang, hal ini dalam pengembangan ilmu melalui tenaga pengajar beserta mahasiswa. Selain tenaga pengajar, mahasiswa juga mampu menerapkan dan mengembangkan ilmu yang telah didapat selain itu juga dapat berinteraksi dengan masyarakat luas. Adapun bentuk produk yang dihasilkan dari pelatihan tersebut di antaranya:
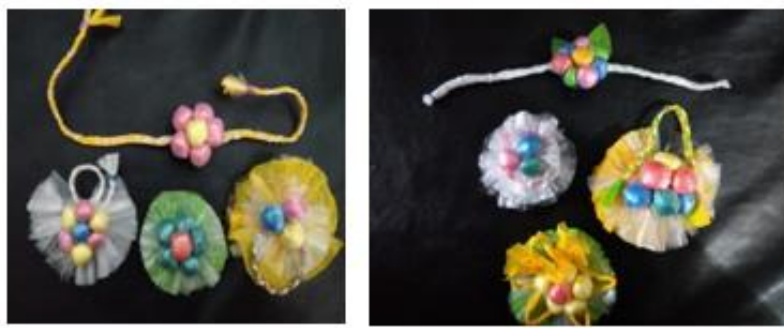

Gambar 1. Karya Peserta Berupa Bros dan Gelang Tangan (Sumber: Jupriani, 2019) 

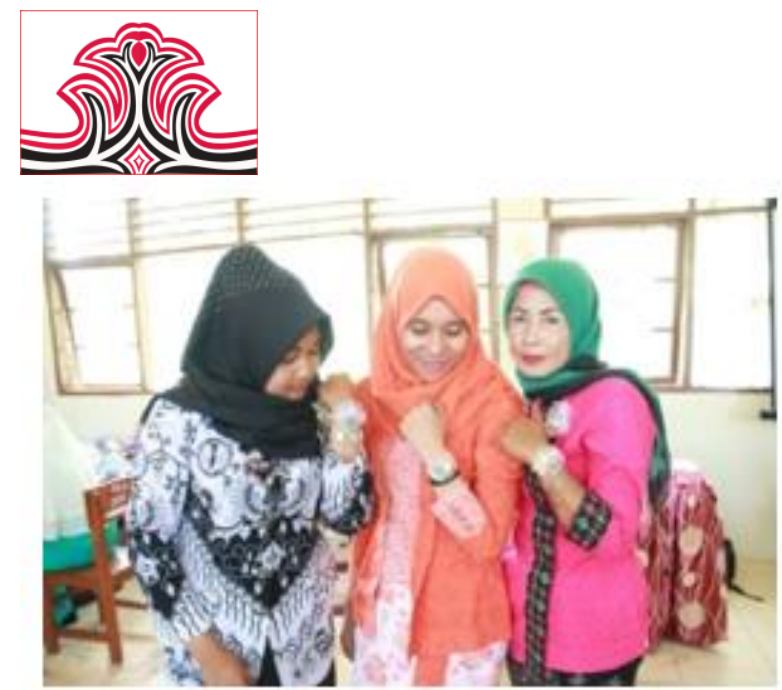

Gambar 2. Karya Gelang Tangan (Sumber: Jupriani, 2019)

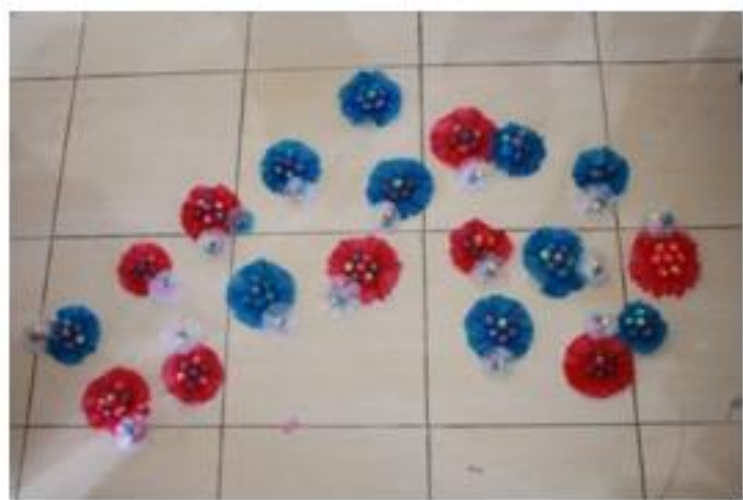

Gambar 3. Bermacam-macam Bros (Sumber: Jupriani, 2019)

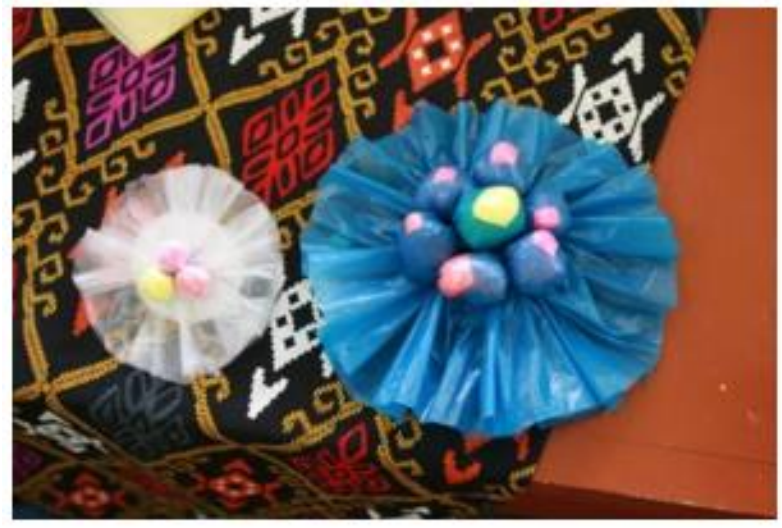

Gambar 4. Bermacam-macam Hiasan Pendukung (Sumber: Jupriani, 2019)
Gorga : Jurnal Seni Rupa

Volume 08 Nomor 02 Juli-Desember 2019 p-ISSN: 2301-5942 | e-ISSN: 2580-2380

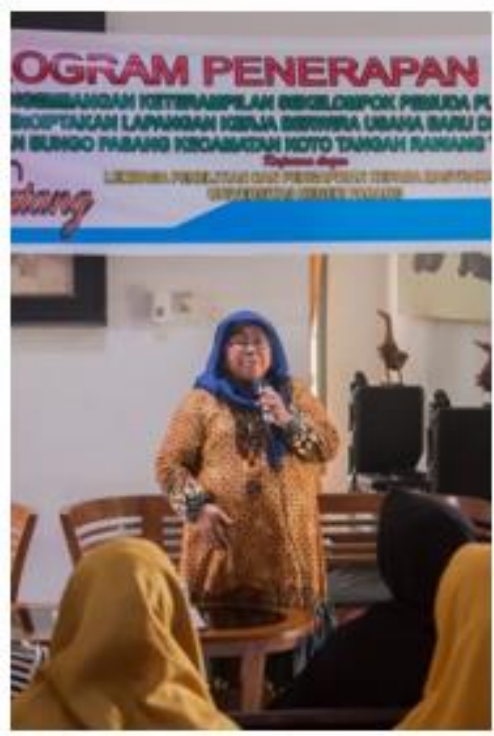

Gambar 5. Ketua Pelaksana Memberikan Pengarahan kepada Peserta Pelatihan

(Sumber: Jupriani, 2019)

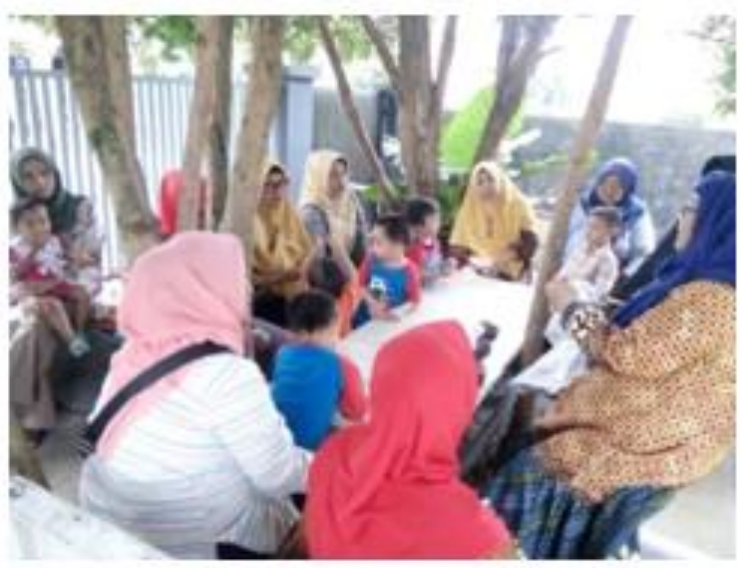

Gambar 6. Menerangkan Alat dan Bahan yang Digunakan oleh Peserta Pelatihan

(Sumber: Jupriani, 2019)

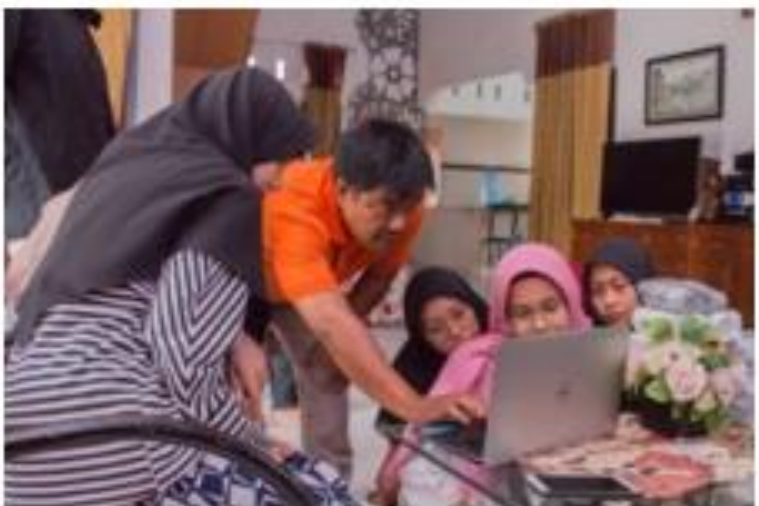

Gambar 7. Pengarahan Menggunakan Komputer oleh Instruktur (Sumber: Jupriani, 2019) 


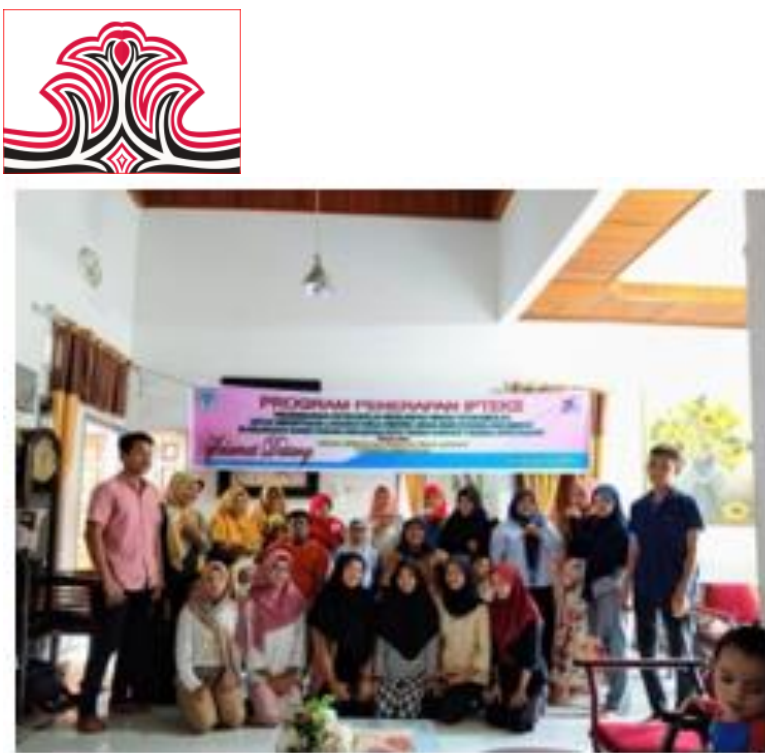

Gambar 8. Suasana Foto Bersama (Sumber: Jupriani, 2019)

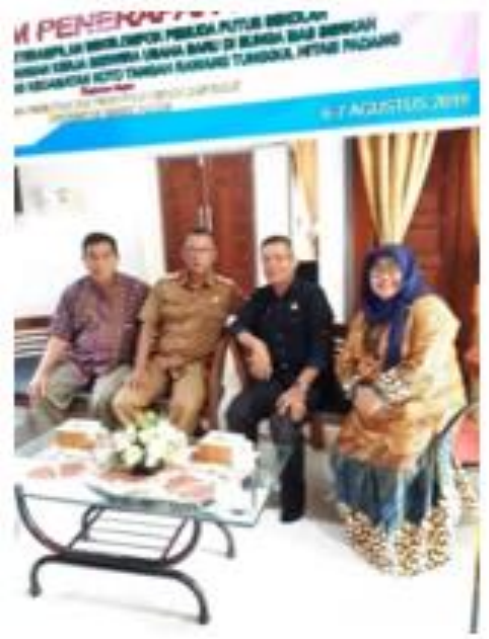

Gambar 9. Menjalin Kerjasama bersama Lurah dan SKPD (Sumber: Jupriani, 2019)

\section{Pembahasan}

Deskripsi kegiatan yang sudah dijalankan pada kegiatan workshop "pengembangan keterampilan Sekelompok pemuda/i putus sekolah, menciptakan lapangan kerja berwirausaha baru di "bunga mas berkah"rawang tunggul hitam". Dalam pembelajaran seni rupa bagi pemuda pemudi putus sekolah telah menghasilkan produk berupa: pin, gelang, bros dan sovenir. Produk yang dibuat merupakan kreasi dari masing-masing peserta, yaitu dari penerapan kreasi. Kreasi yang dibuat berupa kreasi dari beberapa rangkaian bunga yang ada didalam pikiran peserta. Yakni kreasi yang umumnya terdapat pada kraetivitas peserta pelatihan. Merujuk pada kreasi tersebut, tercipta produk pin, bros dan gelang serta benda souvenir yang menarik. Meskipun bentuk kreasi yang dibuat disederhanakan dengan cara mengambil bagian tertentu saja. Namun tetap memperlihatkan bentuk asli untuk memelihara nilai luhur budaya daerah. Seperti yang diungkapkan oleh Gustami (2000) kontinuitas dan perubahan seni kerajinan yang mengandung nilai luhur budaya bangsa akan tetap terpelihara dengan
Gorga : Jurnal Seni Rupa

Volume 08 Nomor 02 Juli-Desember 2019 p-ISSN: 2301-5942 | e-ISSN: 2580-2380

baik, apabila usaha pengembangannya didasarkan atas pemikiran yang rasional, kepekaan cita rasa estetik dan keyakinan iman yang kuat, (2000: 44). Alasan mendasar kenapa menggunakan krasi tersebut adalah untuk tetap mencipkan kreasi hasil budaya, selain untuk memberikan ciri khas terhadap produk yang dibuat. Inilah yang membedakannya dengan produk dari daerah lain meskipun teknik yang digunakan sama.

Hasil nyata yang diperoleh dari kegiatan ini selain produk yang disebutkan di atas, juga berupa skill atau kemampuan bagi peserta pelatihan yaitu para guru sekolah dapat mengembangan keasinya pada murid dan umemiliki pekerjaan tambahan. Peserta memiliki kemampuan untuk membuat beberapa produk dengan teknik merangkai bunga menggunakan bahan bekas. Peserta diberikan bimbingan dan arahan membuat suatu produk mulai dari membuat desain, bagaimana cara membuat desain dan kreasi yang baik. Dilanjutkan dengan cara mengembangkan kerativitas peserta sehingga mendapat hasil yang diinginkan sehingga menghasilkan bentuk yang bagus. Bagaimana cara merangkai bunga yang yang diinginkan tercapai yang siap untuk dipasarkan.

\section{KESIMPULA DAN SARAN \\ 1.Kesimpulan}

Sumatera Barat dikenal sebagai sebuah wilayah yang mempunyai keindahan yang luar biasa. Keindahan yang dimiliki dikenal dengan sebutan "Ranah Minang" ini tidak terlapas dari letaknya yang secara geografis terletak dihamparan bukit barisan. Selain indah wilayah ini juga dikenal dengan kesuburannya, oleh karena itu tidak heran jika hampir semua jenis tanaman dapat tumbuh dengan subur.

Keragaman platik yang dapat digunakan sebagai kebutuhan membawa barang gagangan termasuk pangan dapat dikelola dengan baik oleh masyarakatnya. Hal tersebut membuat masayarakat Sumatera Barat dapat mencukupi kebutuhan masyarakatnya, walaupun tetap harus diakui karena berbagai faktor seperti gagal panen dan lain sebagainya membuat Sumatera Barat harus memasok kebutuhan pangan dari luar daerahnya. Walaupun Sumatera Barat terkenal dengan kekayaan alamnya, namun banyak pihak membenarkan kalau kekayaan yang dimiliki Sumaera Barat selain pangan belum tergali, bahkan nyaris beberapa tanaman yang sangat potensial untuk dijadikan material pokok dalam membuat karya kratif bernilai guna ada yang belum tersentuh. Salah satu contoh material yang dimaksud adalah bahan limbah yang oleh masyarakat yang digunakan sehari-hari disebut "Plastik/kantong" atau dibeberapa tempat ada 
yang menyebut "bahan bekas/limbah". "Plastik" atau "Kantong Kresek" adalah bahan yang terdapat kalau ibik-ibuk belanja ke Pasar, Toko dan sebagainya. Tidak heran jika kantong palstik dapat dilihat diberbagai daerah di Sumatera Barat. Dalam kesempatan ini, tim pelatihan memilih untuk memanfaatkan Kantong Kresek sebagai material pembuatan "bros, gelang dan pin" sebagai alternative peningkatan ekonomi guru seolah diluar jam sekolah dan membuka wawasan pemuda pemu di Dadok. Pelatihan yang dilakukan akhir dapat diambil kesimpulan kalau pemuda-pemudi putus sekolah berpotensi menjadi perajin.

Walaupun Sumatera Barat terkenal dengan kekayaan alamnya, namun banyak pihak membenarkan kalau kekayaan yang dimiliki belum tergali, bahkan nyaris beberapa bahan limbah yang sangat potensial untuk dijadikan material pokok dalam membuat karya kratif bernilai guna ada yang belum tersentuh. Salah satu contoh material yang dimaksud adalah kantong plstik bekas yang oleh masyarakat setempat disebut "Kresek" atau dibeberapa tempat ada yang menyebut "Plastik Asoy". Kesempatan ini, tim pelatihan memilih untuk memanfaatkan "Plastik Asoy" sebagai material pembuatan "Bros dan Gelang" sebagai alternative peningkatan ekonomi pemuda-pemudi putus sekolah. Dengan pelatihan yang dilakukan sebagai audience akhirnya:

* Dapat memahami bahan limbah yang dapat dijadikan material dalam membuat bunga kering sehingga mampu menopang perekomian mereka.

* Dapat memahami proses pengolahan bahan limbah menjadi bahan siap pakai dalam membuat bungan kering, gelang, bebek, bros dan sapu hias.

* Dapat mengaplikasikan bahan bekas yang terdapat di sekitar atau diwilayah pemuda pemudi Dadok Tunggul Hitam, terutama tumbuhan yang disebut masyarakat dengan nama "Plastik Asoy" sehingga aktifitas ini tidak hanya bernilai jual, namun dapat juga menopang perekonomian masayarakat.

\section{Saran}

Menjadikan pemuda pemudi sebagai sasaran bidik program pengabdian pada masyarakat untuk tahun berikutnya.

Memberikan pelatihan dengan rentang waktu yang lebih panjang agar pelatihan benar-benar sampai ketatatran terhalus dan dengan berbagai pengembangan bentuk maupun keindahan.

Memberikan pelatihan yang dapat mendukung dan bermanfaat dari pelatihan yang telah diberikan. Pelatihan pendukung yang dimaksud adalah, pelatihan
Gorga : Jurnal Seni Rupa

Volume 08 Nomor 02 Juli-Desember 2019 p-ISSN: 2301-5942 | e-ISSN: 2580-2380

atau workshop membuat bros, pin, gelang, pelatihan benda souvenir dari bahan limbah plastik dan lain sebagainya.

\section{DAFTAR RUJUKAN}

Amar,L. \& Strugo. (2003). School/Classroom Climate. Diunduh pada 18 Oktober 2019. [Online]. di AvailableFTP: http://go2lily.com/Documents/ School\%20classroom\%20climate.pdf.

Budiwirman. (2016). Seni Grafis \& Perkembangannya ke Desain Grafis. Padang: UNP Press.

Dirbinlitabmas Ditjen Dikti. (1998). 248. Jakarta: PT. Gramedia Pustaka Utama.

Djabar. (1995). Metode Penelitian Komunikasi. Bandung: PT Remaja.

Gustami. (2000). Konsep-Konsep di Balik Kriya

Tradisional Indonesia Analisis Desain Melalui Pendekatan Sosial-budaya. Yogyakarta: ITB.

. (1991). Nilai Ekspor Kerajina Tumbuh 37\%/ Tahun. Harian Kompas, 5 Maret 1991.

Koswara, E. (1998). Dinamika Informasi dalam Era Globalisasi. Bandung: PT Remaja Rosdakarya.

Nurtain. (1989). Supervisi Pengajaran (Teori dan Prektek). Jakarta: Depdikbud.

Sulasmi Darma, Prawira. (1989). Warna Sebagai Salah Satu Unsur Seni dan Desain. Jakarta: P2LPTK Dirjen Dikti Depdikbud. 